\section{UNIVERSITY \\ of DEBRECEN \\ FACULTY OF \\ HEALTH}

NYÍREGYHÁZA

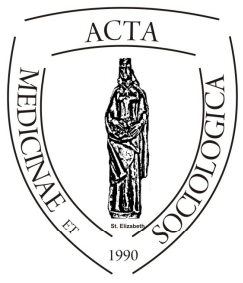

ACTA

MedSoc

VOLUME 5.

2014

\title{
Segítői hivatásra készülő hallgatók coping stratégiáinak megnyilvánulási lehetőségei nehéz, szakmai helyzetek kezelése során
}

\author{
Oroszné Pál Zsuzsanna - Sárváry Andrea \\ Debreceni Egyetem, Egészségügyi Kar
}

\begin{abstract}
We have taught helping students at the University of Debrecen, Faculty of Health for a number of years. Our goal is to train professionals who are competently and effectively carry out their work. In our survey we examine the students' mental health, career motivation, ideas their of the profession, their image of the profession and the skills influencing helping professions skills. The results of this research will be used for the purpose of effective skills development

The helping profession training system includes theoretical knowledge and practical skills, in addition important personality development of the profession (Bagdy E., 1996). For example: empathy, congruent communication, communication awareness, aggression management etc). Training help professionals it also important to achieve a healthy mental status, effective mental capacity as well. Student's career, future career motivation and their mental health status affect the training modules and tailor made trainings.

In the higher education training we have witnessed a significant transformation which is not conducive to training requirements to support the development of personal skills. Over the past two decades, student's expectations towards higer education and motivations have changed, there appeared the postadolescence generations as well.

Our paper is presented as a part of this larger-scale research, which includes the concept of coping, the knowledge of the profession and the image of the profession.
\end{abstract}


We review some previous research on the topic of coping, describing the concept and factors affecting the phenomenon. We determined the students' coping strategies. The results showed that problem-focused coping is the dominant mode, which on the one hand helps in the efficient solution of everyday professional situations, on the other hand it makes the proper management of the emotional situations more difficult. We present the correlations between the coping mechanisms and the professional's career and professional roles. We asked about factors affecting the profession skills, capabilities, advantages and disadvantages, which determine the choice of profession. We analyzed the responses in connection with the difficult, occupational situations. The analysis of the results showed that rational problem solving mode is manifested in students' solutions but this is less consciously, more instinctively. There are few effective means to solve problems, their solution methods show a simple scheme. They are motivated by the support, and they have appropriate empathy and care, which can be built by a controlled and focused facilitator conduct.

Keywords: higher education, mental health status, health psychology, coping strategies, career profiles

DOI: $10.19055 / \mathrm{ams} .2014 .5 / 14-15 / 5$

Összefoglalás. A Debreceni Egyetem Egészségügyi Karán segítő hivatásra készülő hallgatók oktatásában több éve veszünk részt. Célunk olyan szakemberek képzése, akik kompetensként, hatékonyan látják el munkájukat. Kutatásunk során feltérképezzük a hallgatók mentális egészségét, pályaválasztási motivációját, szakmáról való elképzeléseit, szakmai hivatást, hatékony segítői munkát befolyásoló készségeket, képességeket. A kutatás eredményeit a hatékony készségfejlesztés céljára használjuk fel.

A segítő szakmák képzésében a teoretikus tudást és gyakorlati rutint nyújtó (specifikus) tárgyak mellett fontos az ún hivatásszemélyiség (Bagdy E., 1996) fejlesztése. A segítő szakmák esetében pl. empátia, kongruens kommunikáció, kommunikációs tudatosság, agressziókezelés stb, valamint az egészséges mentális státusz, a hatékony pszichés terhelhetőség megvalósítása. A képzési modulok, tréningek egyénekre szabott jellegét befolyásolja a hallgatók pályaképe, pályamotivációja, valamint mentális egészségi állapotuk

A felsőoktatási képzésben jelentős átalakulásoknak vagyunk tanúi, melyek nem kedveznek azon képzési követelményeknek, melyek a szakmai és személyes képességek, készségek fejlődését, fejlesztését segítik elő. Az elmúlt két évtizedben a hallgatói elvárások, motivációk is megváltoztak a felsőoktatással szemben, valamint megjelent a posztadolescens nemzedéke.

Cikkükben ennek a nagyobb volumenü kutatásnak egy részét mutatjuk be, mely során előtérbe kerül a coping fogalma és a szakmáról szerzett ismeretek, és a pályakép jellegzetességei.

Ismertetünk néhány korábbi kutatást a coping témaköréből, mely során tisztázzuk a fogalmat és a jelenséget befolyásoló tényezőket. A hallgatóink coping-stratégiáinak beazonosítása megmutatta, hogy a problémafókuszú megküzdési mód a domináns, mely egyrészt segítséget jelent a mindennapi professzionális helyzetek hatékony megoldásában, másrészt nehezíti az érzelmi helyzetek megfelelő kezelését. A megküzdési módok és a szakmai pályakép, szerep összefüggéseinek bemutatására is vállalkozunk. Megkér- 
deztük a hivatást befolyásoló készségeket, képességeket, előnyöket, hátrányokat, melyek meghatározzák a hivatásválasztást. Nehéz hivatásbeli helyzetekre adott válaszreakciók elemzése arra mutatott rá, hogy hallgatóink problémamegoldásai során a racionális megoldásmód túlsúlya érvényesül, ám ezt kevésbé tudatos szinten, inkább ösztönösen teszik. Kevés eszközzel rendelkeznek a hatékony problémamegoldásra, megoldásmódjaik sémaszerủek. Motiváltak a segítésre, a megfelelő empátiás készséggel, odafigyeléssel rendelkeznek, melyre építhető egy irányított, koncentrált segítői magatartás.

Kulcsszavak: felsőoktatás, mentális státusz, egészségpszichológia, coping stratégiák, pályakép

\section{Bevezetés}

A Debreceni Egyetem Egészségügyi Karán több évtizede folyik a segítő hivatásra készülő hallgatók oktatása. Szociális munkás, védőnő, mentőtiszt, ápoló szakemberek lesznek hallgatóink. Célunk, hogy leendő szakemberként kompetens, hatékony módon lássák el munkájukat, de célunk az is, hogy sikeres, önmagát ismerő, és megfelelő megküzdési képességekkel rendelkező személyiségekké váljanak, hogy saját mentális egészségüket is megőrizhessék.

Napjaink megváltozott társadalmi, gazdasági struktúrájában a segítő hivatás kérdésköre is átalakulóban van. Egyre nagyobb szükség van ilyen szakemberekre, egyre tágabb feladatkörrel, mentális és fizikai leterheléssel, és egyre kevesebb lehetőséggel a szakma hatékony végzéséhez. Kopp Mária és munkatársainak kutatásai (Kopp M. - Kovács M., 2006) is felhívják a figyelmet a magyar lakosság általánosan rossz népegészségügyi állapotára. A magatartásszabályozás zavaraira, a korai stressz, a krónikus stressz negatív hatásaira, a megküzdési stratégiák elégtelen müködésére, az értékrend, a társas kapcsolatok hiányosságaira.

Általánosan ismert tény, hogy a segítő hivatásúak körében nagyobb a burnout kockázata (Cartwright, 1979). Stresszforrásként említhetjük, hogy túl sok beteggel kell foglalkozniuk, kritikus döntéseket kell hozniuk, és a munkafeltételek nem mindenesetben való maximális teljesülése is komoly felelősséget ró rájuk. Kapcsolatuk a beteggel, klienssel és azok hozzátartozóival érzelmileg megterhelö, gyakran szomatikus, mentális állapotukat veszélyezteti. A mindennapi megterhelő fizikai és pszichés igénybevétel következtében az egészségügyi dolgozóknak kifejezetten kedvezőtlen az egészségi állapota, morbiditási és mortalitási mutatói, és körükben gyakori a pszichoszomatikus tüneteik előfordulása (Pikó, 2001; Molnár, 2002; Pikó, 2001). Saját vizsgálatainkban tapasztaltuk mentőtisztek esetében a kiégés nagyobb mértékét, és az egyre fiatalabb korosztály érintettségét (Posgai - Oroszné, 2012). Csabai és munkatársai (Csabai és Barta, 2000) arra hívják fel a figyelmet, hogy az általuk megkérdezett orvostanhallgatók har- 
mada gondolt már arra, hogy befejezi tanulmányait, 20\%-uk azért, mert nem tartja magát alkalmasnak a pályára. Margitics (2006) szubklinikus depresszió meglétét tárta fel föiskolai hallgatók esetében. Ezek az eredmények azt mutatják, hogy már a képzésben fontos a segítöi készségek, kompetenciák hatékony fejlesztése, hiszen a segítő munkában való sikeresség alapvetően befolyásolhatja a mentális állapotot, szomatikus egészséget.

A segítő szakmákra készülő hallgatók, a segítő szakmákban dolgozó szakemberek mentális egészségének vizsgálatára kevés figyelmet fordítunk az egészségügy különböző területein, a „frontvonalon” dolgozó segítőkre, akik nap, mint nap a betegek, kliensek között dolgoznak, kevésbé fókuszálunk. Pszichológiai szempontból egyrészt a segítő kapcsolat fogalomköre adhat magyarázatot arra, hogy miért fontos ezzel a problémával foglalkoznunk. Másrészt a hallgatói, a felsőoktatásban megjelenő változások késztetnek bennünket arra, hogy felhívjuk a figyelmet a korosztály jellegzetességeiből következő, mentális egészséget befolyásoló jelenségekre.

A segítő kapcsolat olyan, növekedést elöidéző folyamat, melynek tagjai és körülményei befolyásolják a gyógyulási folyamatot. Hiszünk a bálinti „kapcsolat, mint gyógyító tényező,, elvében. Bálint szerint az ápoló személyzet személyisége, viselkedése is „gyógyszernek” tekinthető (Molnár - Csabai, 2009). A mindennapi gyógyító munka során a beteg és a segítő szakember közötti interakciónak jelentős szerepe van a gyógyulás, gyógyítási folyamatban. Ez nagy felelősséget és nehéz emocionális és kognitív feladatot is ad az ápoló személyzetnek. Az utóbbi időben megváltoztak a szakemberek és betegek szerepviszonyai, egyre jobban előtérbe kerül a partnerségi viszony, és a betegek részéröl a széleskörü tájékoztatási igény.

A gyógyító szerep pályaszocializációja során ezért a szakmai ismeretek átadásán túl, fontos egy készség, képességrendszer fejlesztése, amely hatékonnyá, tudatossá teszi a segítő kapcsolati rendszer nem specifikus hatótényezőit. Ezek a mindenki számára ismert és elérhető készségek, mint az empátia, kommunikáció, konfliktuskezelés, türelem, stb. hatékony alkalmazása megkönnyíti a gyógyító munkát. Mind a beteg elégedettebb lesz, mind pedig a segítő kompetensebbnek érezheti magát.

Patterson és Eisberg (Bagdy, 1996) által megfogalmazott hatékony segítői tulajdonságok a következőek:

1. Intellektuális kompetencia (jó elméleti felkészültség és szüntelen önképzés)

2. Energia (testi-lelki-kapcsolati müködések energizáltsága)

3. Hajlékonyság, rugalmasság a kliens problémája határozza meg a teendőket, nem a segítő „mihez értése” (módszertani jártassága) 
4. „Nem módszer specifikus” humán segítő tényezők nyújtani tudása (együttérzés, támogatás, megerősítés, személyesség, odaforduló figyelem, ,jelenlét”, légkör, biztonságnyújtás, együttgondolkodás stb.)

5. Jóindulatú alapattitüd

6. Önismeret: Intra- interperszonális személyi(ségi) valamint módszertani technikai kompetencia egyensúlya / „személyesség” személyiség és tudományosság - felkészültség egyensúlya/

Ezen tulajdonságok nem megvalósíthatóak hatékony, egészséges, jól funkcionáló személyiség nélkül, hiszen a mindennapi gyógyító munka során az ápoló szakember a személyiségével vesz részt, annak minden előnyös, hátrányos, tudatos és tudattalan megnyilvánulásával. Ez hat a betegre, ebből nyeri az erőt, a biztonságot, segíti, vagy éppen hátráltatja a gyógyulási folyamatot. A beteggel folytatott közös munka alapja egy mentálisan kiegyensúlyozott szakember, aki kompetens szakmájában, és ennek eredményeképpen egészséges. A kompetencia elégtelen megélése vezethet szomatikus, mentális problémákhoz.

Éppen ezért tartjuk fontosnak a segítő szakmában dolgozó, és már az arra készülő szakemberek mentális egészségének megóvását, megkeresni azokat a tényezőket, amelyek ebben szerepet játszanak. Az egyéni hatékonyság, az énkompetenciák, megküzdési módok széleskörü megismerése adhat választ arra, hogy milyen protektív tényezők segíthetik a szakemberek mindennapjait. Ezen szakemberek mentális egészségének megőrzése kulcsfontosságú az egészségügy rendszerében.

A felsőoktatási képzésben jelentős átalakulásoknak vagyunk tanúi. Az elmúlt két évtizedben a hallgatói elvárások, motivációk is megváltoztak a felsőoktatással szemben, valamint megjelent a posztadolescens nemzedéke. Ez, az az életkor, amelyet a szakirodalom az életkor feladataival összhangban többek között emering adulthood-nak (készülödő felnőttség) (Arnett, 2007), „the boomerang age”-nek (Mitchell, 2007) neveznek. Ezek az elnevezések arra utalnak, hogy a serdülö és felnőttkor között létezik egy átmeneti időszak, ami leginkább a felsőoktatásban lévő és onnan kikerült fiatalokra jellemző. Nagy próbatétel számukra, és krízishelyzetként is értelmezhetö, hogy alkalmazkodniuk kell a bizonytalan emocionális, egzisztenciális létből származó nehézségekhez. A kapunyitási krízis jelensége ez, utalva ezzel az életciklus váltásból származó problémákra (Magyari, 2009). Bizonytalanná válik a pályaválasztás, párválasztás, családalapítás. Sokan a depresszió jeleit mutatják. Margitics (2006) vizsgálatában a főiskolai hallgatók esetén a szubklinikus depresszió fokozott jelenlétét találta, melynek okai között a belső kontroll, az egyéni életvezetési készségek hiányát is látta. Jellemzőek életvezetési, mentálhigiénés, szomatikus problémák, betegségek (Lisznyai, 2010). 


\section{Megküzdési (coping) stratégiák}

A pszichés stresszel és az életeseményekkel foglalkozó kutatók az ötvenes évektől vezették be a „coping” fogalmát. Az angol kifejezés (to cope) a megterhelésekkel való megbirkózást, legyürést vagy azokon úrrá levést jelenti.

Megküzdés alatt a személy azon erőfeszítéseit értjük, melyek arra irányulnak, hogy legyőzze a rá ható külső vagy belső fenyegetéseket. A megküzdés (coping) olyan viselkedéses és intrapszichés mechanizmusokat tartalmaz, melyek segítségével a személy kezelni (megoldani, tolerálni, csökkenteni) tudja a környezeti és belső kihívásokat és a köztük előforduló konfliktusokat (Lazarus és Launier, 1978). A megküzdési folyamat révén az a személy új készségeket, képességeket sajátíthat el, vagyis a stressz hatékony megküzdése hosszabb távon pozitívnak tekinthető, hiszen fejlődéshez segítette hozzá az egyént.

A megküzdési stratégiáknak két főbb formája van (Lazarus, 1991a,b; Lazarus és Folkman, 1984). Az problémaközpontú megküzdés esetében a személy a problémára vagy a helyzetre összpontosítva megpróbálja azt megváltoztatni, illetve a jövőben elkerülni, vagy önmagát próbálja megváltoztatni, fejleszteni.

Az érzelemközpontú megküzdés esetében a személy nem képes közvetlenül a problémával foglalkozni, hanem tudatos vagy tudattalan (pl. elhárító mechanizmusok) stratégiákkal a helyzethez kapcsolódó érzelmi reakciókat igyekszik csökkenteni, ezáltal önmagát feszültségmentesíteni. Ez a stratégia különösen akkor hatékony, ha a személy magát a helyzetet nem képes megváltoztatni, vagy a helyzet eseményei befolyásolhatatlanok.

Az emberek többsége egyaránt használ problémaközpontú és érzelemközpontú megküzdési formákat (lásd még: Atkinson és mtsai, 1997; V. Komlósi, 2000). A különböző stresszhelyzetekhez való leghatékonyabb alkalmazkodás akkor várható az adott személytől, ha minél többféle megküzdési készséggel rendelkezik, és rugalmasan tudja ezeket használni a helyzet követelményeinek megfelelően, akár többet is egyszerre. A stratégiák hatékony alkalmazása függ az egyén korábbi tapasztalataitól, intellektuális képességeitől és önkontrolljától.

\section{A problémaközpontú megküzdés}

Ezt a stratégiát akkor választja az egyén, amikor úgy érzi, hogy van esélye befolyásolni a fennálló vagy fenyegető stresszhelyzetet. A személy arra összpontosít, hogy megkísérelje elkerülni, vagy megváltoztatni a fennálló, számára fenyegető helyzetet. 
Problémaközpontú megküzdéskor először a személy meghatározza a problémát, vagyis végiggondolja, hogy mi okoz számára nehézséget. Ezután számbaveszi a megoldási lehetőségeket, és mérlegeli azok előnyeit és hátrányait. Végül kiválasztja a számára leghatékonyabbnak tűnő megoldást, és végrehajtja.

Ezek a stratégiák irányulhatnak kifelé, a környezet felé, vagyis amikor a személy a környezetében, a helyzetben igyekszik változást elérni. Irányulhatnak azonban befelé is, amikor a személy önmagában igyekszik valamit megváltoztatni (pl. módosítja az igényszintjét, új készségeket sajátít el stb.).

A problémaközpontú megküzdésnek leggyakoribb módjai:

- tárgyalás: az egyén a helyzet többi résztvevőjére próbál hatást gyakorolni (pl. mások meggyőzése, kompromisszumra való törekvés),

- cselekvés: az egyén a probléma megoldására tesz erőfeszítéseket,

- önmagunkban változtatunk meg valamit: pl. tanulással igyekszünk megszerezni valamilyen hiányzó készséget, képességet.

\section{Az érzelemközpontú megküzdés}

Az érzelemközpontú megküzdést akkor választja az egyén, amikor nincs hatása az adott eseményre, pl. szeretett személy halála, munkahelyi elbocsátás. Ilyenkor az egyén a helyzetet nem tudja megváltoztatni.

Ezekben az esetekben a személy célja egyrészt, hogy megakadályozza, hogy a helyzet által keltett negatív érzések elhatalmasodjanak rajta. Másrészt, a személy ezekkel a stratégiákkal elkerüli a probléma megoldásával való foglalkozást.

Az érzelemközpontú megküzdési stratégiák többféleképpen csoportosíthatók. Néhányan viselkedéses és kognitív módszereket különítenek el (Moos, 1988). A viselkedéses technikák közé tartozik az a testmozgás, amit azért végez az egyén, hogy elterelje figyelmét a problémáról. Idetartozik még az alkohol- és drogfogyasztás, vagy az érzelmi támasz keresése a barátoknál. Kognitív stratégiát alkalmaz az a személy, aki időlegesen félreteszi a problémát (,nem gyötrődöm ezzel”), vagy a helyzet jelentését megváltoztatva, újraértékelve csökkenti a kellemetlen érzéseket („nem is fontos nekem ez a dolog”). Bizonyos viselkedéses és kognitív stratégiák nagyon adaptívak, vannak azonban károsak is (pl. túlzott alkoholfogyasztás).

Mások kérődző, elterelő és negatív elkerülő stratégiákat különböztetnek meg az érzelemközpontú megküzdésen belül. A kérődző stratégiák közé tartozik, amikor a személy visszavonul a világtól, hogy töprenghessen a negatív hatás 
következményein, és átadhassa magát gyötrő érzéseinek. Sokat beszél környezetének arról, hogy milyen rossz ez a helyzet, és mennyire kellemetlenül érzi magát, de nem tesz konkrétan semmit a változás érdekében. Ez a stratégia megnyújtja és elmélyíti a rossz hangulatot, és azok, akik ilyen stratégiát választanak, kevésbé hajlanak a probléma aktív megoldására.

Az elterelő stratégiák lényege, hogy az egyén valamilyen kellemes tevékenységbe menekül, pl. sportol, moziba jár, kirándul stb. Ezek alkalmazásával a személy kikapcsolódik (,feltöltődik”), ami segíti önmaga megerősödését, és azt, hogy helyzet fölötti kontrollját visszaszerezze. Ezek a stratégiák megrövidítik és gyengítik a lehangoltságot, és azok, akik ilyen stratégiát alkalmaznak, miután megszabadulnak rossz hangulatuktól, gyakrabban keresik a helyzet aktív megoldását.

A negatív elkerülő stratégiák alkalmazásával a személy potenciálisan veszélyes dolgokkal tereli el figyelmét a problémáról. Idetartozik például a túlzott alkoholfogyasztás, önveszélyes viselkedés (száguldozás motorral/autóval), vagy másokkal szembeni agresszió. Ezek a stratégiák szintén meghosszabbítják és mélyítik a rossz hangulatot, és alkalmazásuk természetesen tovább ront a helyzeten, hosszabb távon akár súlyosabb testi és lelki sérülést is eredményezhetnek.

Lazarus és Folkman (1986) kutatásai eredményeként a problémaközpontú és érzelemközpontú megküzdési formákon belül további nyolcféle stratégia különíthető el, melyek a következők:

- konfrontáció: ez a problémával való szembehelyezkedést, aktív megküzdést jelenti;

- eltávolodás: a helyzettől való érzelmi és mentális távolságtartást jelenti, hogy energiát gyüjthessen a további megküzdéshez;

- érzelmek és viselkedés szabályozása: ez az adott helyzet megoldását legjobban segítő érzelmi kifejezésmód és viselkedés megtalálását jelenti;

- társas támogatás keresése: a társas környezet részéről rendelkezésre álló erőforrások, támogatások keresését és kihasználását jelenti;

- a felelősség vállalása: az észlelt, tulajdonított kontroll vállalása kerül elötérbe ebben az esetben;

- problémamegoldás-tervezés: kifejezetten kognitív, racionális stratégia, azoknak a lehetőségeknek a kiértékelését jelenti, amelyek a helyzet megoldását elősegíthetik; elkerülés-menekülés: nem vállalja a konfrontációt, kilép a szituációból;

- pozitív jelentés keresése: a negatív jelentésü esemény kihívásként, bizonyos szempontból pozitívként való értékelése történik ekkor. 
Lazarus (1990) szerint ezek a stratégiák az egészséges, érett személyiség jellemzői. Patológiás konfliktusmegoldás esetén az érzelmek szabályozása zajlik, elsősorban az énvédelem, a szorongás csökkentése a cél, ez énvédő vagy elhárító mechanizmusokon keresztül zajlik.

\section{Megküzdési stratégiákkal kapcsolatos kutatási eredmények}

A coping stratégiákkal kapcsolatos kutatások jelentős része az életkornak és a nemnek a megküzdési módokkal kapcsolatos összefüggéseire keresték a választ. Amerikai kutatási eredmények szerint a fiatalabb serdülök inkább a szüleikben bíznak, amikor fontos döntést kell meghozniuk, és érzelmi támaszt várnak tölük, az idősebb serdülők inkább probléma megoldó stratégiát alkalmaznak (Hutchinson, Baldwin, Oh, 2006).

Néhány kutató szerint a nem nincs hatással arra, hogy milyen coping stratégiát alkalmaz a fiatal (pl. Hutchinson, Baldwin, Oh, 2006). Mások szerint azonban a lányok inkább kérnek szociális támogatást, mint a fiúk (Copeland, és Hess, 1995; Hess, és Copeland, 2001), és a fiúk inkább problémamegoldó, míg a lányok inkább érzelem fókuszú megküzdési stratégiát használnak (Li és mtsai, 2006). Ez utóbbi kutatás szerint az érzelemfókuszú stratégiát alkalmazók inkább hajlamosak a depresszióra, mint a problémaközpontú stratégiát preferálók, mert aki problémafókuszú megoldásokat alkalmaz, könnyebben tudja az erőforrásait mozgósítani.

A fiúk a stresszel való megküzdés során hajlamosabbak az agresszió és a harag kifejezésére, míg a lányok inkább internalizáló érzelemközpontú viselkedéseket mutatnak (Maschi és mtsai, 2008). Ismét mások azt találták, hogy a fiúk esetében a bünöző magatartás negatív kapcsolatban áll a problémamegoldó copinggal: minél jellemzőbb egy fiúra a bünöző viselkedés, annál kevésbé képes problémamegoldó stratégiát alkalmazni. A kényszeres problémákat mutató fiúk között pedig szignifikánsan többen alkalmaznak érzelemközpontú megküzdést (Compas és mtsai, 1988).

Oláh Attila (1995) nemzetközi kutatásainak eredményei szerint az általa vizsgált (magyar, indiai, olasz, svéd, jemeni) kultúrákban a serdülők alacsony és közepes szorongásszint esetén a megküzdés konstruktív útjait, míg magas szorongásszint esetén az elkerülést alkalmazták mint a feszültséggel való maladaptiv megküzdést. Herman-Stahl és Petersen (1996) kutatásai szintén a depresszió tünettanával együtt járó passzív és elkerülő coping magasabb, a közelítő coping alacsonyabb szintjét mutatták ki serdülőknél.

Margitics Ferenc (2005) föiskolások körében végzett kutatási eredményei szerint a depressziós tünetegyüttessel legszorosabb összefüggést az érzelemköz- 
pontú megküzdési módok mutatták, elsősorban az érzelmi indíttatású cselekvés és a visszahúzódás, valamint a kognitív átstrukturálás hiánya.

Billings és Moos (1984) kutatásaik során azt találták, hogy akik problémaközpontú megküzdést használtak stresszhelyzetekben, mind a stressz alatt, mind a stressz után kevésbé voltak depressziósak. Kínai orvostanhallgatók között végzett kutatás eredményei azt mutatják, hogy depresszív hangulatú és nem depreszszív hangulatú hallgatók egyenlő mértékben használtak olyan megküzdési módokat, mint a problémamegoldás és kognitív átstrukturálás. A depresszív hangulatú hallgatók esetében azonban ezen stratégiák hatékonyságát csökkentette a problémán való tünődés és passzivitás. Ezen kívül hajlamosak voltak a probléma elkerülésére és tagadására is (Chan, 1992).

Hazai felmérések szerint a kockázatos vagy passzív coping mechanizmus használata rontja a pszichoszociális egészséget serdülőkorban (Pikó és Keresztes, 2001). A problémaközpontú megküzdés jobb alkalmazkodó képességgel van kapcsolatban, míg az, aki emóciófókuszú stratégiákat alkalmaz, több problémával küzd (Li és mtsai, 2006).

A kötődési stílus és a nehéz élethelyzetben alkalmazott megküzdési mód öszszefüggésére irányuló amerikai kutatás a biztonságosan kötődő serdülők esetében magas kommunikációt és alacsony szintű elkerülésre irányuló megküzdést talált. A bizonytalan kötődésű serdülők inkább az elkerülésre irányuló problémamegoldó stratégiát választják, feltehetően azért, mert ők a társakban kevésbé bíznak, a támogatásra érdemtelennek érzik magukat (Howard és Medway, 2004).

\section{Vizsgálat a Debreceni Egyetem Egészségügyi Kar hallgatói körében}

Kutatásunkban arra keresünk választ, hogy a megváltozott társadalmi, gazdasági viszonyok, a fiatalok megváltozott lehetőségei között milyen fontos egészségmegőrző, protektív tényezőket azonosíthatunk a mentális egészség megvalósítása érdekében. Fő irányvonalunk az előzőekben vázolt coping stratégiák feltérképezése. Ezek a megküzdési jellegzetességek jól mérhetőek és jól megnyilvánulóak a viselkedésben. Célunk volt annak megismerése, hogy a megkérdezettek hogyan gondolkodnak saját megküzdési módjaikról. Valamint azt is szerettük volna feltérképezni, hogy viselkedési szinten, nehéz szakmai helyzetek kezelése során hogyan nyilvánulnak meg ezek a coping stratégiák. Található-e összefüggés a megküzdési móddal való önjellemzés és a viselkedéses megnyilvánulások között. Hipotéziseink a következők voltak: 
1. A megkérdezett hallgatók főképp racionális, problémafókuszú megküzdési móddal jellemezhetőek.

2. A problémafókuszú megküzdési mód viselkedési szinten a nehéz helyzetek kognitív megoldásában nyilvánul meg.

3. A megkérdezett hallgatók kevésbé jellemezhetőek emóciófókuszú megküzdési móddal, így az érzelmek kifejezése, empátia kevésbé nyilvánul meg a nehéz helyzetek megoldásában.

4. A megkérdezettek kevés eszközzel rendelkeznek a nehéz helyzetek megoldásában.

\section{Vizsgált személyek}

A vizsgálatban elsőéves, segítő szakmára készülő hallgatók vettek részt, diplomás ápolók, mentőtisztek, szülésznők, egészségügyi ügyvitelszervezők. Az alábbi diagram (1. számú ábra) mutatja a megkérdezettek nem és alapszak szerinti megoszlását.

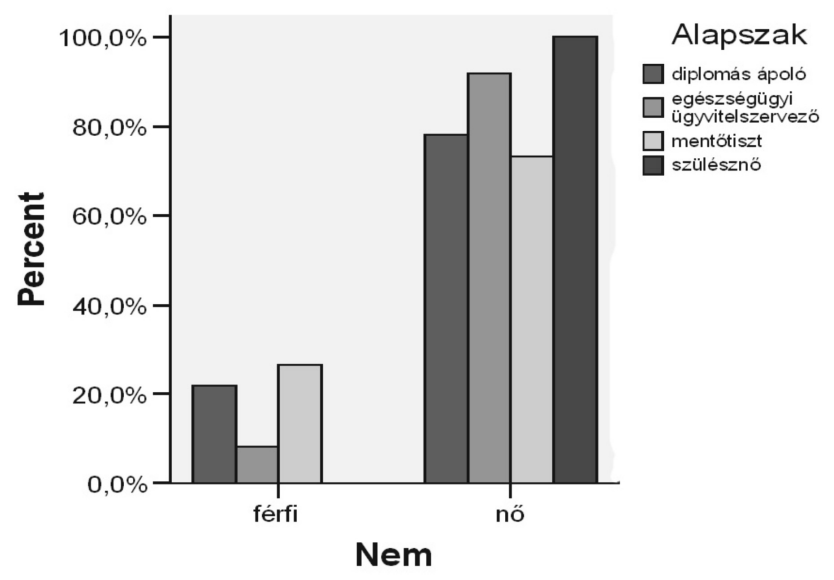

1. számú ábra.

A vizsgálati személyek nemek és szakok szerinti megoszlása. 


\section{Vizsgálati módszer}

A Megküzdési Módok Kérdőív eredeti változatát, Folkman és Lazarus dolgozta ki 1980-ban, ami 68 kérdésből állt. Kopp Mária és Skrabski Árpád vizsgálatai alapján, kialakították az eredeti kérdőív rövidítetett változatát, ami jelenleg 22 tételből áll, hogy minden faktor a legjellemzőbb tételeivel szerepel. A kérdőív a hét probléma megoldási faktorra kérdez rá. A problémaelemzés, a céltudatos cselekvésre, amik a problémamegoldó konfliktusmegoldásra irányul. Az érzelmi indíttatású cselekvésre, az alkalmazkodásra, a segítségkérésre, az érzelmi egyensúly keresésére, és a visszahúzódásra. Ezek a kérdéscsoportok pedig az érzelemi problémamegoldásokra irányulnak. A kérdésekre 0-tól 3-ig - a nem volt rá jellemzö, az alig volt rá jellemző, jellemző, és a nagyon jellemző válaszok lehetségesek.

Nehéz segítői helyzetek bemutatására egy olyan filmet választottunk, ami a segítői hivatásra készülők számára példaértékű szakmai hozzáállást mutat be. Patch Adams története, aki igazi orvos lett, és forradalmasította a gyógyítást az emberekhez való viszonyával, hozzáállásával. 1969-ben a nyugtalan egyetemista Patch önként jelentkezik pszichiátriai kezelésre. Az osztályon hamar kitünik segítőkészségével. Rájön, hogy sokan közülük félrekezeltek, elhagyottak. Patch értelmet talál társai felvidításában, az intézetből kikerülve komolyan veszi orvosi tanulmányait. Jó eredményei ellenére tanárai ellenzik furcsa gyógyítási szokásait. Szerintük Patch lejáratja szakmájukat viselkedésével. Hamar összetüzésbe kerül a felsőbb orvosi hatóságokkal is, de társai, a nővérek és leginkább a betegek védelmükbe veszik a mindig mosolyra kész doktort. A jókedvet, a személyességet, az emberséget jeleníti meg a gyógyításban, és rámutat arra, hogy az intézményi rendszer müködése hogyan hathat mindezek ellen.

A filmböl öt jelentet választottunk ki, melyet a következő instrukcióval dolgoztuk fel. „A következőkben a filmnézés kapcsán 5 jelenetre fogunk rákérdezni. A jelenet elején megállítjuk a filmet és arra kérjük, hogy írja le véleményét arról, hogy mit tenne ÖN a segítő szerepében az adott problémahelyzetben" Az öt jelenet a következő volt:

1. Pszichiátriai, téveszmékkel küzdő beteg szorongásának oldása, félelmeinek csökkentését célzó éjszaka játszódó jelenet.

2. Szorongó, cukorbeteg hölgy a kórház folyosóján egyedül fekszik, az orvosok, orvostanhallgatók mellette, de személytelenként kezelik a beteget.

3. Leukémiás gyermekek csendes kórterme, alvó, szorongó gyermekekkel való kapcsolat létesítése

4. Haldokló beteg kórházi ágya mellett, a beteg támogatása

5. Idős, nem evő hölgy, minden táplálékot visszautasít, hangulata deprimált. 


\section{Eredmények}

A jelenetek feldolgozása során a tartalomelemzés technikáját alkalmaztuk. Ez alapján 11 válaszkategóriát határoztunk meg, melyeket az alábbiakban ismertetünk.

A hibás gondolkodás megváltoztatása kategória arra a megoldásmódra irányul, amikor a beteg gondolkodását próbálja a segítő megváltoztatni. Például a pszichiátriai beteg esetében a téveszmékről próbálta meggyőzni, hogy „,azok csak a fejében léteznek". A hallgatóink ezt a megoldásmódot kevésbé preferálják, tisztában vannak azzal, hogy a beteg gondolkodásmódja adott, ennek befolyásolása nem vezethet eredményre.

A racionális problémamegoldás a válaszok azon részét képezik, amelyek a beteg értelmére, kognitív struktúrájára próbál hatni. Például a téveszmékkel küzdő beteg esteében „megmagyarázom, hogy a mókusok nem bántanak”. Vagy a haldokló beteg esetében „elmondom neki, hogy szép helyre kerül majd a túlvilágon". Ezt a megoldásmódot széles körben alkalmazzák a segítő hivatásra készülök. A problémák kognitív szintü megoldásmódját eszköznek használják fel a segítés során, mint ahogy majd a későbbiekben is ismertetjük. Azonban ez nem elégséges a kompetens szakmai viselkedéshez, ennek tudatosítása fontos feladata az oktatásnak.

A problémamegoldás cselekvéssel kategória aktivitást feltételez, a nehéz helyzeteket cselekvéssel oldom meg. Például a nem evő idős hölgy esetében „megfőzöm a kedvenc ételét, megetetem”. A hallgatók harmada nem visz aktivitást, cselekvést a megoldásmódokba. Az általuk végzett szakmák megfelelő müveléséhez ez a fajta viselkedés elengedhetetlen. Ennek megtanulása és a tanultak alkalmazása szintén az oktatásba beépítendő feladat.

Az okok feltérképezése kategória diagnosztikus célzatú válaszokat tartalmaz. Például az idős nem evő hölgy esetében „megkérdezem, miért nem eszik”. A diagnosztikus elemek kevésbé jelennek meg a hallgatók gondolkodásában. Az okok, azok a tényezők, amelyek a probléma kialakulásához vezettek, úgy tünik nem eszköz a megkérdezettek kezében. A gyógyító munka során az azonnali cselekvés, a tünetek, következmények enyhítése a feladat, így természetes módon az előzmények feltérképezése háttérbe szorul, de sok esetben befolyásolja a gyógyító folyamatot, ezért ismerete, alkalmazása szintén fontos.

Az empátia megnyilvánulási módjai is megtalálhatóak. Szinte valamennyi jelenetben használják a megkérdezettek. Ilyen válaszok tartoznak ide, mint „együtt érzek vele, megnyugtatom, átérzem a helyzetét". Nagyon fontos az optimális empátiás készség a segítő szakmában dolgozók esetében. Az első éves hallgatók megfelelő odafordulással, együttérzéssel jellemezhetőek. 
A segítői attitüdök a következő válaszokat fedik le. „kedves vagyok, segítek neki, meghallgatom, mesét olvasok, türelmes vagyok, stb.” ebben a kategóriában is találhatunk számos megoldást. Ezek is olyan intrapszichés mechanizmusok, amelyek alkalmazása elengedhetetlen a gyógyítói munka során. Megkérdezettjeink gyakran alkalmazzák ezeket is.

A játékosság kategória kevésbé volt népszerü. A leukémiás gyermekek esetében célzottan jelent meg, valamint a pszichiátriai beteg estében.

$\mathrm{Az}$ énbevonódás kevésbé választott kategória. Saját élmények átadása, saját emlékek megosztása a beteggel tartozik ide. „Elmondom, hogy én mit tettem ebben az esetben." A segítő saját mentális egészségének megörzése és hatékony munkavégzése érdekében kerülje ezt az alkalmazási módot. Hallgatóink is tudják ezt, kis számban választották.

A kreativitás a szokatlan, újszerủ megoldásmódokat igénylő válaszokat írta le. Hallgatóink találékonysága alacsony színvonalú, csupán néhányan kerültek ebbe a kategóriába. Például a téveszmékkel küzdő beteget próbálja az egyik válaszadó aprólékosan, részletesen hozzászoktatni a félelme tárgyához, a behaviorista deszenzitizációs technika pontosságával.

Inadekvát, a helyzetbe nem illő megoldást adó válaszok száma is kevés volt. A leukémiás gyermekek esetében előfordult válasz: „sírva kirohannék”.

Külső segítség igénybevétele kategória szintén kevésbé alkalmazott viselkedési megnyilvánulási mód. Érvényesül itt a gyógyító munkáról való individualista felfogásmód, az önálló cselekvésre való igény, és az az elképzelés, hogy a munka során az egyéni felelősségvállalás érvényesül. Hallgatóink nehezen kérnek segítséget, és nehezen ismerik fel azokat a helyzeteket, ahol már nem kompetensek. Ezeket a határokat, készségeket is fejleszteni kell.

Az előbbiekben bemutatott kategóriákra kapott válaszok előfordulási gyakoriságát (0-szor, 1-szer, ....5-ször választották, tehát egy jelenetre, vagy kettöre, vagy....mind az 5 jelenetben előfordult) az 2. számú táblázat mutatja be: láthatjuk, hogy a zömében kognitív megoldások mellett megjelenik a segíteni akarás attitüdje, valamint az empátiás készség is nagy változatosságot mutat, ami jelzi a hallgatók szakma iránti érzékenységét. Azonban a kreativitás és külső segítség igénybevételének hiánya a szakmai tudatosság fejlesztésének szükségszerüségére hívja fel a figyelmet. 


\begin{tabular}{|l|c|c|c|c|c|c|}
\hline & 0 & 1 & 2 & 3 & 4 & 5 \\
\hline $\begin{array}{l}\text { Hibás gondolkodás meg- } \\
\text { változtatása }\end{array}$ & $\mathbf{6 9 , 1 \%}$ & $27,2 \%$ & $3,7 \%$ & & & \\
\hline $\begin{array}{l}\text { Racionális problémameg- } \\
\text { oldás }\end{array}$ & $13,0 \%$ & $\mathbf{3 2 , 5 \%}$ & $\mathbf{2 6 , 4 \%}$ & $18,3 \%$ & $9,3 \%$ & $0,4 \%$ \\
\hline $\begin{array}{l}\text { Problémamegoldás cse- } \\
\text { lekvéssel }\end{array}$ & $\mathbf{3 1 , 7 \%}$ & $\mathbf{3 9 , 8 \%}$ & $23,6 \%$ & $4,9 \%$ & & \\
\hline Okok feltérképezése & $\mathbf{7 8 , 0 \%}$ & $19,5 \%$ & $2,4 \%$ & & & \\
\hline Empátia & $7,7 \%$ & $16,7 \%$ & $\mathbf{3 2 , 9 \%}$ & $\mathbf{3 0 , 9 \%}$ & $11,8 \%$ & \\
\hline Segítői attitüd & $5,3 \%$ & $10,2 \%$ & $\mathbf{2 3 , 6 \%}$ & $\mathbf{2 9 , 7 \%}$ & $\mathbf{2 3 , 6 \%}$ & $7,7 \%$ \\
\hline Játékosság & $\mathbf{6 0 , 2 \%}$ & $33,7 \%$ & $6,1 \%$ & & & \\
\hline Énbevonódás & $\mathbf{9 0 , 7 \%}$ & $8,5 \%$ & $0,8 \%$ & & & \\
\hline Kreativitás & $\mathbf{8 1 , 7 \%}$ & $17,1 \%$ & $0,8 \%$ & $0,4 \%$ & & \\
\hline Inadekvát válaszok & $\mathbf{8 2 , 5 \%}$ & $15,9 \%$ & $1,6 \%$ & & & \\
\hline $\begin{array}{l}\text { Külsó segítség igénybevé- } \\
\text { tele }\end{array}$ & $\mathbf{8 6 , 6 \%}$ & $13,0 \%$ & $0,4 \%$ & & & \\
\hline
\end{tabular}

2. számú táblázat.

A filmjelenetekkel kapcsolatos tartalomelemzés eredményei.

A 3. számú táblázatban láthatjuk, hogy a megküzdési módokkal hogyan jellemzik önmagukat a segítő hivatásra készülö hallgatók.

\begin{tabular}{|c|c|}
\hline MEGKÜZDÉSI MÓD & Gyakoriság \\
\hline Problémaelemzés & $83 \%$ \\
\hline Segítségkérés & $77 \%$ \\
\hline Céltudatos cselekvés & $76 \%$ \\
\hline Érzelmi egyensúly keresése & $69 \%$ \\
\hline Alkalmazkodás & $68 \%$ \\
\hline Visszahúzódás & $50 \%$ \\
\hline Érzelmi indíttatású cselekvés & $25 \%$ \\
\hline
\end{tabular}

3. számú táblázat.

A megküzdési módok gyakorisága.

Láthatjuk, hogy a problémafókuszú megküzdési módok (problémaelemzés, céltudatos cselekvés) túlsúlya érvényesül. Az emóciófókuszú megküzdési módok közül az érzelmi egyensúly keresése, az alkalmazkodás és a segítségkérés coping stratégiákkal szintén nagyobb arányban jellemzik önmagukat. A visszahúzódás megküzdési módra adott önjellemzések kevésbé dominánsak. Az érzelmi indíttatású cselekvés a megkérdezettek közel harmadára jellemző. 
A megküzdési módok ilyen megoszlása több kérdést is felvet. Egyrészt a segítői hivatás a problémaelemzést kívánja meg. Így szerencsések a kapott önjellemzések. Másrészt a kapott eredményekben tükröződnek a modern társadalom elvárásai, napjaink teljesítményorientált értékei. Az individualizmus, az aktivitás preferenciája, ami a segítő szakma hatékonyságát csökkenti, színvonalát mérsékelheti. Harmadrészt a segítői hivatás igényli az érzelmek megfelelő kezelését is, ami a kapott eredmények alapján nehézséget okoz hallgatóinknak.

A 4. táblázat az önjellemzésen alapuló megküzdési stratégiák és a filmjelenetekkel kapcsolatosan felmerülő viselkedések közötti kapcsolatokat Pearson korrelációk értékével szemlélteti. Bemutatja azokat az összefüggéseket, melyek a megküzdési módok önjellemzése és a nehéz helyzetekre adott reakciókból következtethetőek.

\begin{tabular}{|c|c|c|c|c|c|}
\hline \multirow[t]{2}{*}{$\begin{array}{l}\text { Megküzdési } \\
\text { módok }\end{array}$} & \multicolumn{5}{|c|}{$\begin{array}{l}\text { Önmagamról feltételezett válaszreakció, a nehéz helyzetek } \\
\text { kezelése során, a filmjelenetek elemzésekor }\end{array}$} \\
\hline & $\begin{array}{l}\text { Racioná- } \\
\text { lis } \\
\text { probléma } \\
\text { meg- } \\
\text { oldás }\end{array}$ & $\begin{array}{l}\text { Probléma } \\
\text { megol- } \\
\text { dás cse- } \\
\text { lekvéssel }\end{array}$ & Empátia & $\begin{array}{l}\text { Segítői } \\
\text { attitüd }\end{array}$ & $\begin{array}{c}\text { Énbevo- } \\
\text { nódás }\end{array}$ \\
\hline $\begin{array}{l}\text { Problémaelem- } \\
\text { zés }\end{array}$ & $\begin{array}{l}0,22 \\
(0,000)\end{array}$ & & $\begin{array}{l}0,15) \\
(0,016)\end{array}$ & $\begin{array}{l}0,17) \\
(0,007)\end{array}$ & \\
\hline $\begin{array}{l}\text { Céltudatos cse- } \\
\text { lekvés }\end{array}$ & $\begin{array}{l}0,156 \\
(0,014)\end{array}$ & & & $\begin{array}{l}0,207) \\
(0,001)\end{array}$ & \\
\hline $\begin{array}{l}\text { Érzelmi indítta- } \\
\text { tású cselekvés }\end{array}$ & & & & & \\
\hline Alkalmazkodás & & & & & \\
\hline Segítségkérés & $\begin{array}{l}0,150 \\
(0,019)\end{array}$ & & $\begin{array}{l}0,199 \\
(0,002)\end{array}$ & & \\
\hline $\begin{array}{l}\text { Érzelmi egyen- } \\
\text { súly keresése }\end{array}$ & & $\begin{array}{l}0,157 \\
(0,013)\end{array}$ & & & \\
\hline Visszahúzódás & & & & & $\begin{array}{l}0,146 \\
(0,022)\end{array}$ \\
\hline
\end{tabular}

4. táblázat. Az önjellemzésen alapuló megküzdési stratégiák és a filmjelenetekkel kapcsolatosan felmerülő viselkedések közötti kapcsolatok. Zárójelben a Pearson-féle korrelációs együttható értékei szerepelnek. 
Mint láthatjuk, néhány szignifikáns összefüggést találhatunk a megküzdési módok és a filmjelenetekkel kapcsolatosan feltételezett viselkedési reakciók között.

Az egyik domináns tendencia, miszerint a hallgatók a filmjelenetek kapcsán az önmagukról feltételezett viselkedési reakció során a problémafókuszú megoldásmódokat preferálják, mint az önjellemzés alapján is. Ezeket megfelelő hatékonysággal alkalmazzák racionális, kognitív szinten, azonban az aktivitás, ami a segítő hivatás elengedhetetlen feltétele, a hatékony cselekvés eszközei hiányoznak készségeik közül. Ezzel párhuzamosan megjelenik az empátia, a segítői attitüd, szintén, mint számukra kognitív megoldási mód a nehéz helyzetek kezelésére. Problémát jelent számukra elkülöníteni a segítői szándék jelenlétét, a tényleges hatékony segítéstől. Természetesen életkoruk, tapasztalataik, tanulmányi előrehaladásuk alapján nem kívánjuk ennek teljes ismeretét, de fontos szempont az oktatás és a mindennapi munka során, hogy a segíteni akarás, amellyel szerencsés módon tudatos szinten rendelkeznek a hallgatóink, nem egyenlő a segítéssel. Van szándék, és motiváció, de ehhez megfelelö, tudatosan használt eszközökre is szükség van.

A másik tendencia, hogy az emóciófókuszú megküzdési módok és a nehéz helyzetekre adott válaszmódok között kevés korrelációt találhatunk, szintén jó prognózis lehet a szakmai identitás fejlesztéséhez, hiszen az érzelmi kontroll, az érzelmek tudatos megélése hallgatóink esetében jelen lehet a nehéz helyzetek kezelésében. Szakmai helyzetben inkább racionális énjüket veszik elő, de figyelnünk kell arra, hogy azokban az esetekben is, amikor emocionális, segítői attitüdre lenne szükség.

Mint azt a 4. számú táblázatban láthatjuk, a korrelációk alacsonyak, mert a kapcsolat nem lineáris a vizsgált változók között. E helyett inkább küszöb jellegü, tehát ha az egyik változó értéke elér egy bizonyos szintet, akkor a másik változó átlaga is magasabb lesz. A következő ábrák (5-9. ábra) tanulmányozása alapján árnyaltabb képet kaphatunk a kapcsolatokról. A függőleges tengely a megküzdési módot ábrázolja, míg a vízszintes tengelyen a nehéz helyzetekre adott válaszok előfordulási gyakoriságát szemléltetjük. 


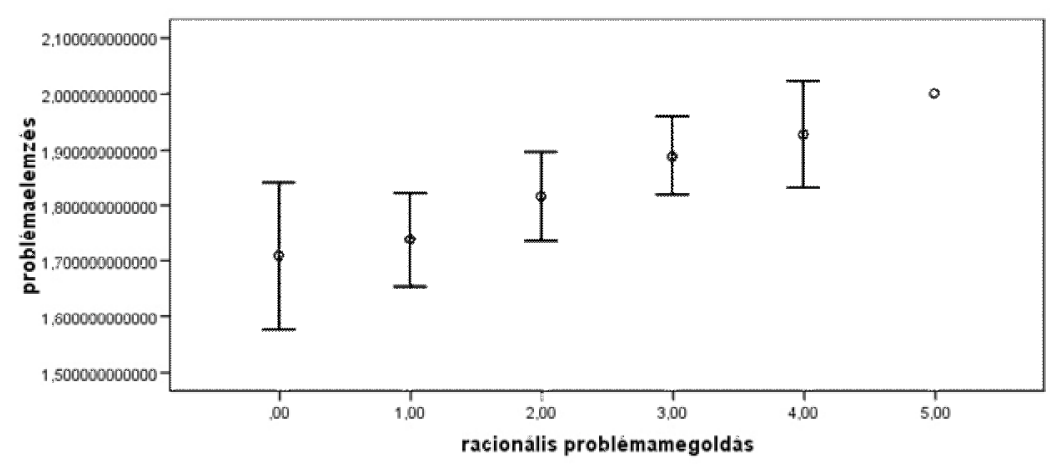

5. ábra.

A problémaelemzés, mint megküzdési mód és a racionális problémamegoldás, mint lehetséges válaszlehetőség összefüggése a csoportátlagok és a hozzájuk tartozó konfidencia intervallumok alapján

A 5. ábrán, a problémaelemzés megküzdési móddal önjellemzett hallgatók esetében a vizsgált összefüggés azt mutatja, hogy a racionális problémaelemzés, mint válaszlehetőség alkalmazása során a problémaelemző megküzdési mód akkor érvényesül igazán, ha több, változatos válaszlehetőséget képes adni a hallgató.

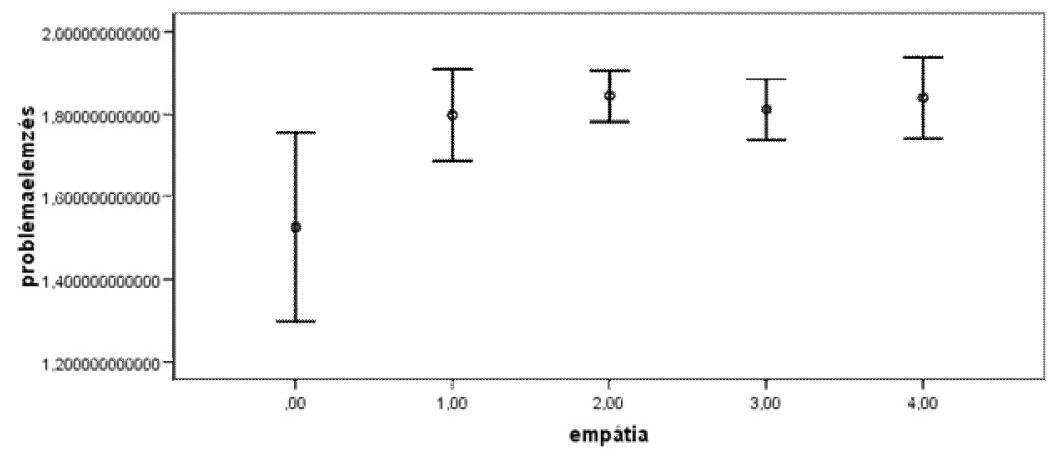

6 .ábra.

A problémaelemzés, mint megküzdési mód és az empátia, mint lehetséges válaszlehetőség összefüggése a csoportátlagok és a hozzájuk tartozó konfidencia intervallumok alapján. 


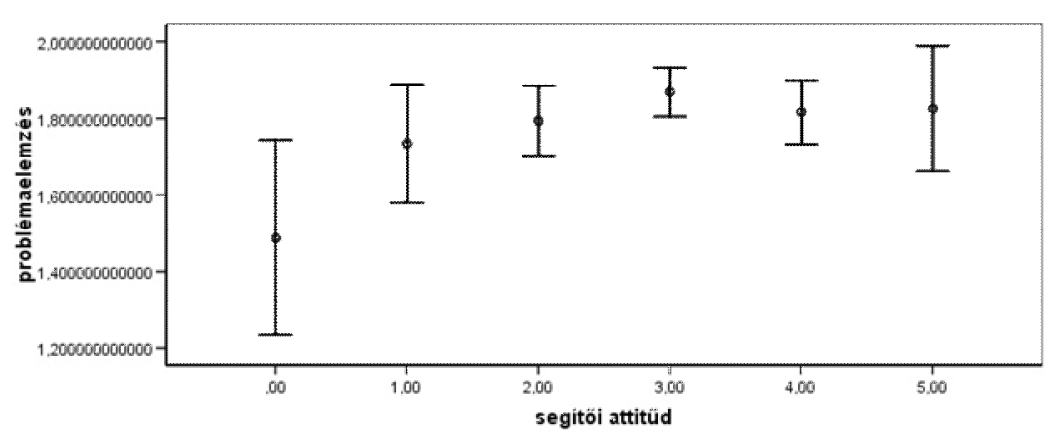

7 .ábra.

A problémaelemzés, mint megküzdési mód és a segítői attitüd, mint lehetséges válaszlehetőség összefüggése a csoportátlagok és a hozzájuk tartozó konfidencia intervallumok alapján.

A segítői attitüdök, az empátia esetében az igaz, hogy a vizsgált szakmai helyzetekben tanúsított legalább egy ilyen megnyilvánulás eredményesebb problémamegoldáshoz vezet, de a több ilyen megnyilvánulás nem jelent hatékonyabb problémaelemző coping stratégiát (6-7.ábra).

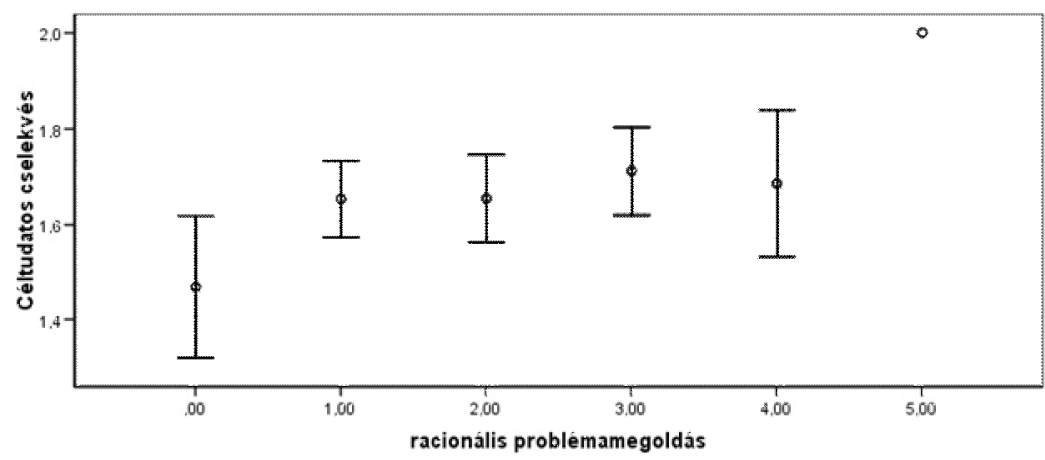

8. ábra.

A céltudatos cselekvés, mint megküzdési mód és a racionális problémamegoldás, mint lehetséges válaszlehetőség összefüggése a csoportátlagok és a hozzájuk tartozó konfidencia intervallumok alapján. 


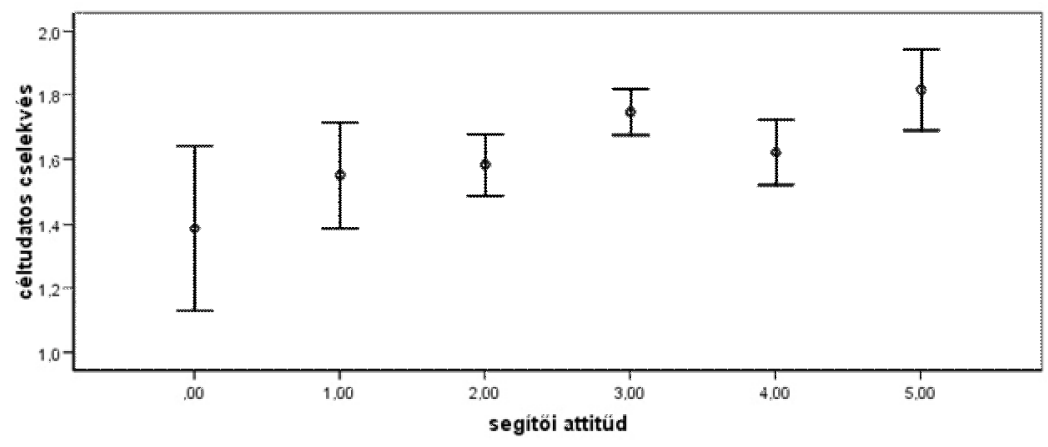

9. ábra.

A céltudatos cselekvés, mint megküzdési mód és a segítői attitűd, mint lehetséges válaszlehetőség összefüggése a csoportátlagok és a hozzájuk tartozó konfidencia intervallumok alapján.

A céltudatos cselekvés, mint megküzdési mód akkor jelenik meg hatékonyan, ha a hallgató (legalább egyszer) megmutatta, hogy a szakmai helyzeteket képes kognitív síkon megoldani, illetve kompetens a segítöi attitüdök alkalmazásában (8-9. ábra).

Mint láthatjuk, (5-9 ábrákon) a problémaelemzés, és céltudatos cselekvés, mint problémafókuszú megküzdéssel jellemzettek nagyobb mértékben alkalmazzák a racionális problémamegoldás kategóriát, valamint ők azok, akik hatékonyan használják az empátia és segítői attitüd eszközöket nehéz helyzetek kezelésekor. A hallgatók nagyobb része azonban nem rendelkezik azzal a képességgel, hogy különböző helyzetekben differenciáltan tudjon viselkedni (lásd. 2. sz. táblázat), így a megoldásmódjaikban a problémafókuszú megküzdési módok dominálnak. Így a beteggel való kapcsolatot a kognitív mechanizmusok hatják át, a segítést is ebből a megközelítésből értelmezik.

Szintén ezt támasztja alá, hogy az érzelmi fókuszú megküzdési módok közül, az érzelmi egyensúly keresése coping stratégiát azok vallják magukra nézve jellemzőbbnek, akiknél az aktivitás, cselekvés választása a leggyakoribb - ötből három alkalommal. Ez arra utal, hogy érzelmi stabilitást a cselekvés, aktivitás útján érhetik el (10. ábra). 


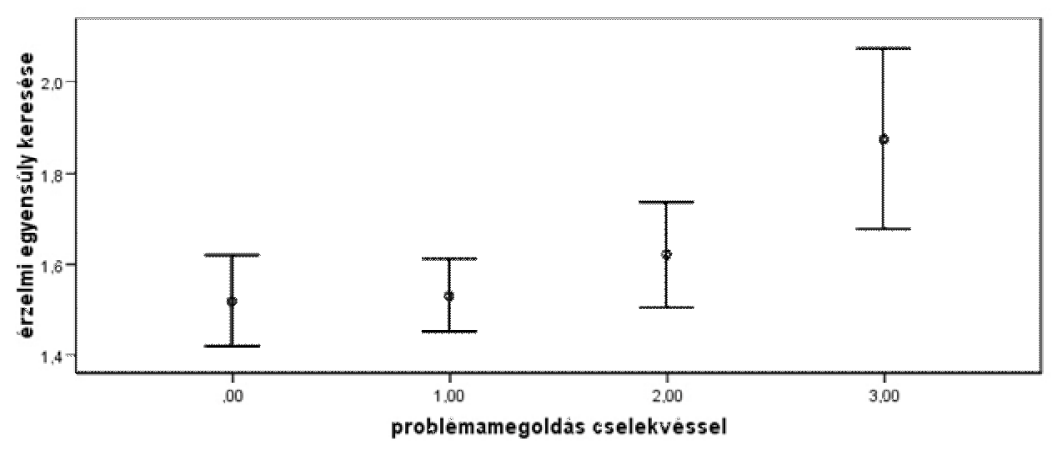

10. ábra.

Az érzelmi egyensúly keresése, mint megküzdési mód és a problémamegoldás cselekvéssel, mint lehetséges válaszlehetőség összefüggése a csoportátlagok és a hozzájuk tartozó konfidencia intervallumok alapján.

A segítségkérés érzelmi fókuszú megküzdési móddal önmagukat jellemzők esetében, mint ahogyan az alábbi ábrákon (11., 12. ábra) láthatjuk, érvényesül a racionális problémamegoldás, és az empátia eszközeinek alkalmazása.

Úgy tünik, a racionális problémamegoldás és az empátia megnyilvánulásai növelik a segítségkérés coping stratégia alkalmazásának esélyét, e megnyilvánulások közepes szintjéig (maximum 2). Ahhoz, hogy a segítségkérés tudatosan alkalmazott megküzdési mód legyen a szakmai munka során feltehetően szükséges a válaszra váró helyzetek kognitív differenciálása és az empátiás készség alkalmazása.

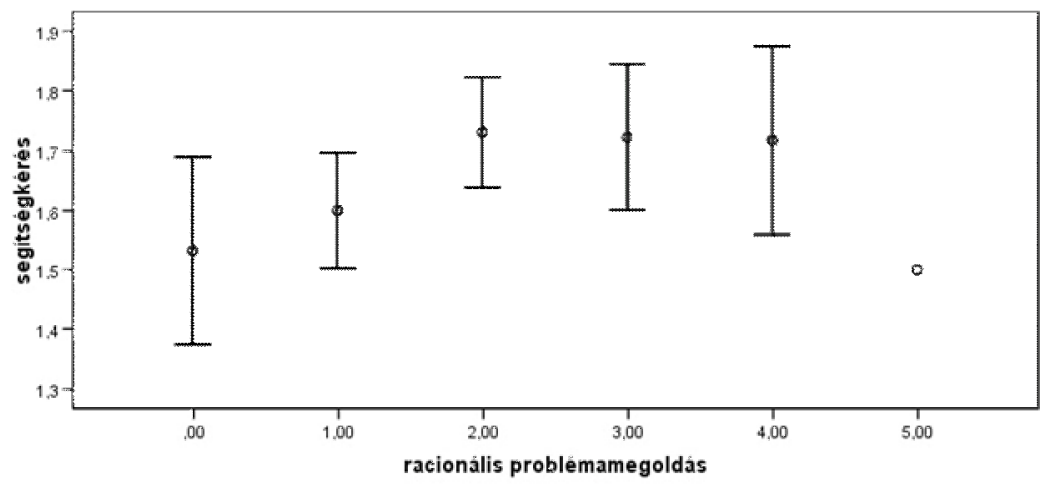

11. ábra.

A segítségkérés, mint megküzdési mód és a racionális problémamegoldás, mint lehetséges válaszlehetőség összefüggése a csoportátlagok és a hozzájuk tartozó konfidencia intervallumok alapján. 


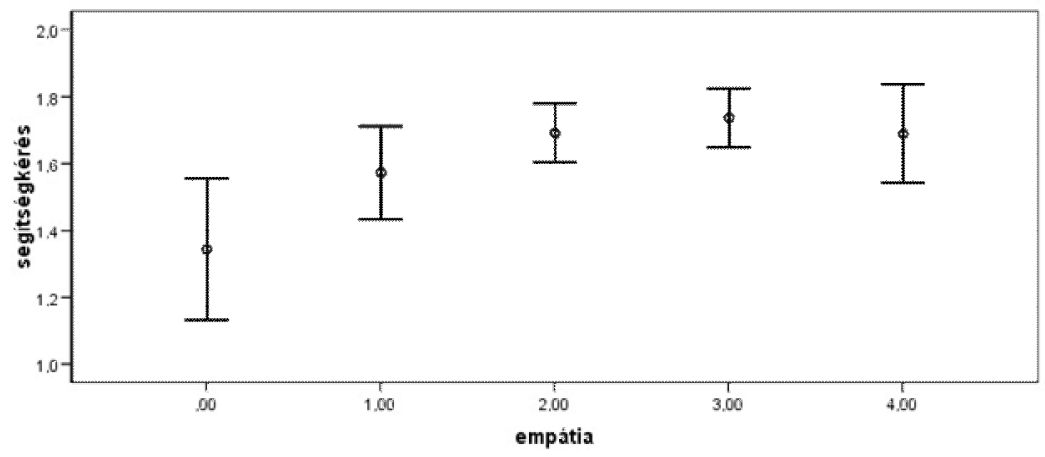

12. ábra.

A segítségkérés, mint megküzdési mód és az empátia, mint lehetséges válaszlehetőség összefüggése a csoportátlagok és a hozzájuk tartozó konfidencia intervallumok alapján.

\section{Összefoglalás}

Az első hipotézisben feltételeztük, hogy problémafókuszú megküzdési módokkal jellemzik önmagukat hallgatóink, ami igazolódott. Önmagukat a szakma és a társadalmi igények, az iskolai teljesítménymotiváció eredményeképpen problémamegoldónak jellemzik Az érzelmi fókuszú megküzdési módok közül a segítségkérés jelenik meg nagyobb arányban, ami jelzi a motiváltságot, igényt, a belevonódást, a segítő szakma iránt.

Második feltételezésünk, miszerint a problémafókuszú megküzdési mód viselkedési szinten a nehéz helyzetek kognitív megoldásában nyilvánul meg, részben igazolódott. A megkérdezettek a nehéz helyzetek kezelésében kognitív szintü megoldásokat preferálnak, azonban kevés aktivitást visznek bele válaszaikba, és kevésbé kreatívak. Azonban a racionális gondolkodást igénylő válaszok alacsony gyakoriságot mutatnak, szemben, az érzelmi töltetű empátia és segítői attitüd válaszlehetőségekkel. Ez utóbbiak nagy százalékban, a jelenetek között szélesebb eloszlásban jelennek meg a válaszadók között. A hallgatók értik, érzik a problémahelyzetek súlyát, de kevés tényleges eszközzel rendelkeznek ezek megoldására. Inkább az empátia, a segítői attitüd megoldásmódok ösztönös preferálásával találkozhatunk. Míg a segítségkérés, mint copingstratégiával nagyobb mértékben jellemzik önmagukat, addig a segítségkérés, mint lehetséges megoldási mód a beteggel való kapcsolat során kevésbé jelenik meg. A segítői szakmai hivatás szempontjából lényeges problémafókuszú coping stratégiák azokban az esetekben lehetnek hatékonyak, amikor a hallgató képes a helyzetek 
között differenciálni, több válaszlehetőséget alkalmazni és képes a segítői attitüdök és az empátia tudatos alkalmazására. Ha ez nincs jelen, akkor a mindennapokban használt racionális megküzdési mód ösztönösen érvényesülhet a segítői viselkedés mögött. A hallgató érti, érzi a segítő attitűd fontosságát, képes az empátiára, de ezt kevésbé tudatosan irányítva teszi.

Harmadik hipotézisünkben feltételeztük, hogy a megkérdezett hallgatók kevésbé jellemezhetőek emóciófókuszú megküzdési móddal, így az érzelmek kifejezése, empátia kevésbé nyilvánul meg a nehéz helyzetek megoldásában. A kapott eredmények alapján ez részben igazolódott. Az emóció fókuszú coping stratégiák kevesebb arányban fordultak elő hallgatóink önjellemzésében, viszont a nehéz helyzetek kezelése során domináns megoldásmódok voltak a segítői magatartások, és az empátia. Azonban ezeknek a szakmai helyzetekben való kompetens alkalmazása problémát jelent hallgatóink számára. Elméleti ismeretek jelennek meg, tudják, motiváltak a hallgatók a segítésre, de ezeket az ismereteket a készségek, képességek fejlesztésével, a tapasztalatok szerzésével kell formálni.

A negyedik feltételezésünk, miszerint kevés eszközzel rendelkeznek a beteggel való problémamegoldás terén, beigazolódott. Alacsony válaszgyakorisággal, sémaszerü megoldásmódokkal, kevés kreativitással jellemezhetőek válaszaik. Az empátia, segítői attitüd jelenléte mellett ezek szakszerű alkalmazásának hiányát tapasztalhatjuk. A segítői eszközök elsajátítása fontos, komoly feladat, hiszen e nélkül munkájuk és saját mentális egészségük megóvásának eredményessége kérdőjelezhető meg. Fontos megállapítanunk, hogy kevés inadekvát megoldásmód jelenik meg válaszaikban, igaz kevésbé kreatívak, de motiváltak, és szeretnék a segítést megfelelő hatékonysággal, kompetenciával végezni.

Nekünk oktatóknak ezek az eredmények figyelemreméltó üzeneteket közvetítenek. Egyrészt a racionalitás túlsúlya, az érzelmekkel való nehézkes bánásmód megjelenése felhívja a figyelmet arra, hogy az emóciók közvetítésével, értelmezésével foglalkozni kell. Másrészt eszközöket kell adni számukra, hogy valóban segítőként, a beteg és önmaguk javára tudjanak részt venni a gyógyító munkában. Harmadrészt a motiváltságukat, igényüket az empátiás megnyilvánulásokra, a segítői magatartásra tiszteletben kell tartanunk és helyes útra kell terelnünk.

Az ember -a segítő pedig különösen- ismerje a saját határait és azt igyekezzen betartani, és betartatni saját mentálhigiénéje érdekében. Mint ahogy erről szól Gautama Szidhárta története, aki csak akkor talált rá az arany középútra, miután tanúja volt egy zenemüvész és tanítványa beszélgetésének: „Ha túlfeszíted a húrt, elpattan. Ha laza nem szól. Közepesen feszesnek kell lennie.” Ezt az arany középutat, egyensúlyt kell megtalálnia és alkalmaznia annak, aki segítöként, terapeutaként mást kíván erre rávezetni - nem bedőlve a társadalom teljesítménykényszerének, sem a saját elvárásainak. 


\section{Felhasznált irodalom}

1. Arnett, J., J. (2007): Emerging Adulthood: What Is It, and What Is It Good For? Child Development Perspectives, Volume 1, Issue 2, pages 68-73, December 2007.

2. Atkinson, R. L., Atkinson, R. C., Smith, E. E., és Bem, D. J., (1997) Stressz. In: Atkinson, R. L., Atkinson, R. C., Smith, E. E., and Bem, D. J., Pszichológia. Osiris Kiadó, Budapest. 422-449.

3. Bagdy E.(1996): Hivatás és személyiség In.:Bagdy Emőke (szerk) A pedagógus

4. Billings, A. G., and Moos, R. H., (1984) Coping, stress and social resources among adults with unipolar depression. Journal of Personality and Social Psychology. 46. 887-891.

5. Cartwright, D., (1979): Contemporary Social Psychology in Historical Perspective, Social Psychology Quarterly, 1, 82-93.

6. Chan, D. W., (1992) Coping with depressed mood among Chinese medical students in Hong Kong. Journal of Affective Disorders, 24. 2. sz. 109-116.

7. Compas, B. E., Malcarne, V. L., Fondacoro, K. M., (1988) Coping With Stressful Events in Older Children and Young Adolescents. Journal of Consulting and Clinical Psychology, 56(3), 405-411.

8. Copeland, E., and Hess, R., (1995) Differences in young adolescents' coping strategies based on gender and ethnicity. Journal of Early Adolescence, 15(2), 203-219.

9. Csabai Márta - Barta Krisztina (2000): Az orvosi identitás alakulása: orvostanhallgatók nézete az orvosi pályáról, az orvosszerepről. Lege Artis Medicinae. 10, 638-644

10. Herman-Stahl, M. A. and Petersen, A. C., (1996) The protective role of coping and social resources for depressive symtomps among young adolescents. Journal of Youth and Adolescence, 25. 733-753.

11. Hutchinson, S. L., Baldwin, C. K., Oh, S., (2006) Adolescent Coping: Exploring Adolescents' Leisure-Based Responses to Stress. Leisure Sciences, 28, 115-131.

12. Hess, S., and Copeland, E., (2001) Students' stress, coping strategies, and school completion: A longitudinal perspective. School Psychology Quarterly, 16(4), 389-405.

13. Howard, M. S., Medway, F. J., (2004) Adolescents' Attachment and Coping With Stress. Psychology in the Schools, 41(3), 391-402.

14. Kopp Mária-Kovács Mónika Erika (2006): A magyar népesség életminősége az ezredfordulón Semmelweis Kiadó, Budapest 
15. Lazarus, R. S., (1990) Stress, coping and ilness. In: Friedman H. S. (szerk.): Personality and disease. Wiley, New York. 84-86.

16. Lazarus, R. S., (1991a) Cognition and motivation in emotion. American Psychologist, 46, 352-367.

17. Lazarus, R. S., (1991b) Emotion and Adaptation. New York: Oxford University Press.

18. Lazarus , R. S., and Folkman, S., (1984) Stress, Appraisal, and Coping. New York: Springer.

19. Lazarus, R. S., and Folkman, S., (1986) Coping and adaptation. In: Gentry W. D. (szerk.): The handbook of behavioral medicine. Guilford, New York. 235-312.

20. Lazarus, R. S., and Launier, R., (1978) Stress-related transactions between person and environment. In: Pervi, L. A., and Lewis, M. (eds.) Internal and external determinants of behavior. Plenum Press, New York.

21. Li, C. E., DiGiuseppe, R., Froh, J., (2006) The Roles of Sex, Gender, and Coping in Adolescent Depression. Adolescence, 41(163), 409-415.

22. Lisznyai Sándor (2010): Készülődő felnőttség. Kutatás a fiatalok mentálhigiénés állapota témakörében In: Életszakaszok határán Közösségi és egyéni tanulási feladatok szerk: Puskás-Vajda Zs. - Lisznyai S. FETA Könyvek 5. Budapest

23. Magyari Judit (2009): A családi narratívák és a jövőtől való szorongás öszszefüggései pályakezdő fiataloknál In: Egy igazolt praxis felé Újabb eredmények a pszichológia és a felsőoktatási tanácsadás hazai kutatásaiból szer: Puskás-Vajda Zs. - Lisznyai S. FETA Könyvek 4. Budapest

24. Margitics, F., (2005) A depresszív élményfeldolgozás háttértényezői főiskolai hallgatóknál. Mentálhigiéné és Pszichoszomatika, 6. 3. sz. 197-230.

25. Margitics Ferenc (2006): A szubklinikus depressziós tünetegyüttes háttértényezőinek vizsgálata föiskolai hallgatóknál Doktori értekezés, Debreceni Egyetem

26. Maschi, T., Morgen, K., Bradley, C., Hatcher, S. S., (2008) Exploring Gender Differences on Internalizing and Externalizing Behavior Among Maltreated Youth: Implications for Social Work Action. Child Adolescent Social Work Journal, 25, 531-547.

27. Mitchell, B. A. (2007) The Boomerang Age: Transitions to Adulthood in Families. Transaction Publishers, U.S.A. Murdock, N. L., \& Gore

28. Molnár Edit (2002): Ápolók egészségi állapota. Nővér, 15. 4. 4-10

29. Molnár Péter - Csabai Márta (2009): Orvosi pszichológia és klinikai egészségpszichológia, Medicina Könyvkiadó

30. Moos, R. H., (1988) Coping Responses Inventory Manual. Stanford University, Palo Alto. 
31. Oláh, A., (1995) Coping strategies among adolescents: A cross cultural study. Journal of Adolescence, 18. 4. sz. 491-512.

32. Pikó, B., Keresztes, N., (2001) Serdülők egészségmagatartása két szociális megküzdési (coping) mechanizmus tükrében. Magyar Pszichológiai Szemle, 62(2), 203-214.

33. Pikó Bettina (2001): A nővéri munka magatartástudományi vizsgálata: pszichoszomatikus tünetek - munkahelyi stressz - társas támogatás. Lege Artis Medicinae, 11. 4. 318-325.

34. Pikó Bettina, Piczil Márta (2006): A pszichoszociális munkakörnyezeti jellemzők összefüggése az elégedettséggel nővérek körében. Mentálhigiéné és Pszichoszomatika, 7. 4. 301-310.

35. Posgai Beáta - Oroszné Pál Zsuzsanna (2011): Kiégés és kontrollfunkciók a mentőtiszteknél TDK pályamunka

36. V. Komlósi, A., (2000) A személyiség értelmezései. In: Oláh, A., és Bugán, A., (szerk.) Fejezetek a pszichológia alapterületeiből. ELTE Eötvös kiadó, Budapest. 189-275.

Oroszné Pál Zsuzsanna: pszichológus, fôiskolai tanársegéd

Debreceni Egyetem Egészségügyi Kar, 4400 Nyíregyháza, Sóstói u. 2-4.

Sárváry Andrea: pszichológus, föiskolai docens

Debreceni Egyetem Egészségügyi Kar, 4400 Nyíregyháza, Sóstói u. 2-4. 